\title{
The effects of an organic rearing system and dietary supplementation of an essential oil mixture on performance and meat yield of slow-growing broilers in two seasons
}

\author{
K. Küçükyılmaz ${ }^{1 \#}$, M. Bozkurt ${ }^{2}$, M. Çınar ${ }^{2}$, A.U. Çatıı' ${ }^{2}$ E. Bintaş ${ }^{2}$ \& R. Erkek ${ }^{3}$ \\ ${ }^{1}$ Department of Animal Science, Faculty of Agriculture, Eskişehir Osmangazi University, Eskişehir, Turkey \\ ${ }^{2}$ Erbeyli Poultry Research Institute - Aydın/Turkey \\ ${ }^{3}$ Department of Animal Science, Faculty of Agriculture, Ege University, İzmir, Turkey
}

(Received 13 May 2014; Accepted 10 October 2014; First published online 19 November 2014)

Copyright resides with the authors in terms of the Creative Commons Attribution 2.5 South African Licence.
See: http://creativecommons.org/licenses/by/2.5/za
Condition of use: The user may copy, distribute, transmit and adapt the work, but must recognise the authors and the South African
Journal of Animal Science.

\begin{abstract}
In this study, performance and carcass characteristics of slow-growing broiler chicks, reared in organic or conventional systems, and fed a diet with an essential oil mixture (EOM, $48 \mathrm{mg} / \mathrm{kg}$ diet), were evaluated in the autumn and spring seasons. The rearing system affected several performance indices, including body weight, feed intake and feed conversion ratio (FCR), but not mortality, within a high statistical significance at 42 and 81 days of age. However, this was observed only from 1 to 42 days in the spring trial. Dietary administration with EOM worsened the FCR at 42 and at 81 days of age in the autumn trial, but not in spring. Organically reared slow-growing chickens consumed less feed mixture per unit of body weight gain, but attained a higher final weight compared with those kept indoors. However, the effect was more pronounced in autumn, which displayed cooler temperatures and robust plant cover availability (i.e. lucerne and trifolium). The carcass yield and cut-up carcass yield were not affected by the rearing system, but EOM diet supplementation increased breast yield only in the spring. The results suggest that autumn conditions promote efficient organic chicken production in the subtropical climatic zone. The amount of herbage consumed represented up to $10 \%$ and $3 \%$ of the birds' daily protein and ether extract requirements, respectively. Supplementing the diet with a mixture of plant essential oils did not support the hypothesis that phytogenic compounds may favourably affect gut function and poultry performance.
\end{abstract}

Keywords: Broiler, carcass characteristics, essential oil, organic, performance

${ }^{\#}$ Corresponding author: kamilk@ogu.edu.tr

\section{Introduction}

Contemporary commercial broiler hybrids attain a market weight within 40 days with an enormous feed conversion efficiency and the display of high edible cut yields. However, fast-growing modern lines have led to welfare concerns, especially because of the rise of metabolic disorders (Owens et al., 2006). Selection for fast growth and high yield may also have affected the sensory and functional qualities of the meat (Dransfield \& Sosnicki, 1999). Therefore, consumers have become increasingly interested in products derived from free-range and organic production. Slow-growing broiler chicks have been used extensively for this purpose with great success. Slow-growing genotypes are more mobile and possess a greater pasture attitude and higher resistance to the poorer conditions of the organic system than the faster-growing hybrids (Castellini et al., 2002a). Slow-growing chicken genotypes require a longer fattening period and are well adapted to outdoor farming conditions (Fanatico et al., 2005). One of the most successful specialty poultry production systems in Europe is the French Label Rouge programme, which requires an outdoor area (Mikulski et al., 2011).

Recently, more studies have begun to compare organic, free-range and conventional broiler meat quality (Castellini et al., 2002b; Owens et al., 2006; Husak et al., 2008). However, relatively few have assessed the growth performance or meat yield of slow-growing broiler genotypes grown with or without outdoor access (Fanatico et al., 2005; Owens et al., 2006; Wang et al., 2009; Mikulski et al., 2011).

Essential oils (EOs), also known as volatile or ethereal oils, are aromatic oily liquids obtained from plant materials (flowers, buds, seeds, leaves, twigs, bark, herbs, wood, fruits or roots). Essential oils contain 
complex mixtures of secondary plant metabolites, consisting of low-boiling phenylpropenes and terpenes, and are extracted with various distillation methods, such as steam (Williams \& Rosa, 2001; Greathead, 2003). Essential oils are an alternative dietary supplement that was proposed after antibiotic growth promoters (AGPs) had been removed from poultry diets in the European Union (EU) (Greathead, 2003; Wallace et al., 2010). Essential oils have been documented to possess various biological activities, such as antimicrobial (Cowan, 1999), antioxidant (Basmacıoğlu et al., 2004), antifungal (Shin \& Lim, 2004) and coccidiostatic (Bozkurt et al., 2012b), and to stimulate digestive enzyme activity (Jamroz et al., 2005). Indeed, a series of scientific reports and field trials have demonstrated that the addition of EOs, individually or in combination, promotes zootechnical performance, including bodyweight gain, feed efficiency and viability (Williams \& Rosa, 2001; Alçiçek et al., 2004; Bozkurt et al., 2009) of fast-growing broilers. However, only one previous report (Waldenstedt, 2003) has discussed the addition EO of oregano to the diet of the chicks fattened for 55 days. The results indicated that vaccination against coccidiosis in combination with an in-feed proprietary product (Orego-Stim) containing oregano oil may be an alternative control method for intestinal health in organically reared chickens. However, there is a paucity of evidence that demonstrates a seasonal effect on the productivity of organic broiler production.

The purpose of the present study was therefore to evaluate the performance and carcass characteristics of slow-growing broiler chicks reared in organic or conventional systems in the autumn and spring seasons. Additionally, we aimed to investigate the efficacy of an EO blend that was screened for its ability to enhance growth performance under these seasonal and rearing systems.

For this purpose, performance indices and the carcass characteristics of chicks were assessed under two seasonal conditions, namely in autumn and spring.

\section{Materials and Methods}

Two trials were conducted in autumn (1 October to 20 December) and spring (12 April to 3 July) at the Poultry Research Institute, Aydın, Turkey, which is situated between $36^{\circ}$ and $38^{\circ}$ northern latitude and between $26^{\circ}$ and $28^{\circ}$ eastern longitude, $60 \mathrm{~m}$ above sea level. The same experimental protocols were followed in the two trials, which lasted for 12 weeks. The effects of the rearing system and essential oil mixture (EOM) supplementation on slow-growing broiler performance and carcass characteristics were assessed. The autumn experiment exhibited an average daily mean temperature of $14^{\circ} \mathrm{C}$ (mean of the highest temperature was $23^{\circ} \mathrm{C}$, and the lowest was $5^{\circ} \mathrm{C}$ ) and six days of rain. The spring experiments exhibited an average daily mean temperature of $25^{\circ} \mathrm{C}$ (mean of the highest temperature was $33^{\circ} \mathrm{C}$, and the lowest was $18^{\circ} \mathrm{C}$ ) and six days of rain. The distance between the organic and conventional rearing units was 50 metres.

A total of 1600 one-day-old mixed-sex Hubbard Red-JA broiler chicks were used in this study. This certified slow-growing breed can adapt to a free-range environment and was produced by crossing slowgrowing JA-57 females with fast-growing M 99 males. Eight hundred broiler chicks in each trial (i.e. autumn or spring) were randomly assigned to four groups, each comprising four identical subgroups (50 chicks per replicate). Thus, each trial was arranged in a $2 \times 2$ factorial design with two rearing systems (organic and conventional) and two feed additive programmes (with or without EOM).

Four hundred organically reared one-day-old broiler chickens were randomly allotted by body weight to two treatments with four replicates each. One of the four replicates was fed a basal diet, while the remaining birds were fed a diet supplemented with EOM. Each replicate was housed in a $10 \mathrm{~m}^{2}$ enclosed floor pen (all-litter) shelter and provided with a $200 \mathrm{~m}^{2}$ outdoor area (paddock) $\left(4 \mathrm{~m}^{2}\right.$ per bird in the paddock). The organic rearing unit was established on $1680 \mathrm{~m}^{2}$, which comprised eight adjacent parcels, which each occupied $210 \mathrm{~m}^{2}$. The pens at the parcel centre were composed of insulated aluminium panels on an iron frame, and windows were placed on one side of the house to allow daylight to enter. These indoor pens measured $3.30 \mathrm{~m} \times 3.05 \mathrm{~m}\left(5 \mathrm{birds} / \mathrm{m}^{2}\right)$ and were equipped with two circular hanging feeders $(5 \mathrm{~cm}$ feeder space/bird), a bell drinker, and a three-tier perch $(15 \mathrm{~cm} / \mathrm{bird})$. Pine wood shavings were spread at $6 \mathrm{~cm}$ depth throughout the concentrate floor. Each pen contained a thermostatically controlled electric brooder, which was used to provide additional heat during brooding. Two bell drinkers and two perches were available throughout the paddock. The ambient temperature was maintained at $33 \pm 1{ }^{\circ} \mathrm{C}$ for the first three days and gradually decreased over three weeks to acclimatize chicks to the outdoors.

Organically reared broiler chicks housed in their acclimatized shelters were permitted outdoor access only after 21 days. The total outdoor period lasted 60 days, during which the broilers reached an age of 81 days. The birds could access the outdoors from their indoor pens through two pop holes measuring $50 \times 50$ $\mathrm{cm}$. They were open during daylight hours, ensuring free access to the outdoor approximately $14 \mathrm{~h}$ daily (between 7:00 and 21:00). Then, birds were confined to indoor pens at night. Artificial light was provided continuously at night only for the first three days to adapt birds to the environment. From day 4, the photoperiod was limited to natural daylight, which was approximately $14 \mathrm{~h}$ light/day. This precise lighting 
programme was also applied in the conventional rearing system. Ground and overhead predators were excluded with net fencing and netting over the paddock.

The natural grassland was completely covered with a lucern (Medicago sativa) and trifolium (Trifolium repens) mixture, which was available for consumption in the paddock after three weeks (i.e. 22 to 81 days of age). Birds foraged uniformly over the paddocks and grazed the herbage completely until slaughter age. Therefore, we assumed that herbage intake equalled the herbage present on that particular area at the start of the experiment. The grassland of each paddock was irrigated regularly by spraying semi-weekly; approximating 50 litres of underground water per $\mathrm{m}^{2}$ outdoor area after the birds were confined to their shelters at night. To estimate the intake of grazed herbage, the sward-cutting technique described by Lantinga et al. (2004) was applied. Using a metallic frame $(0.50 \mathrm{~m} \times 0.50 \mathrm{~m})$ with a fixed cutting height of 2 $\mathrm{cm}$, herbage samples were collected before the outdoor period (at d 21) in each of the eight paddocks and analysed separately. In both seasons, one herbage sample was obtained per paddock. Because herbage was not available in the paddocks when the experiment ended ( $d$ 81), subsequent measurements were not obtained. The samples were dried for $72 \mathrm{~h}$ at $70^{\circ} \mathrm{C}$ to determine the dry matter (DM) content. The Kjeldahl method was used to determine the nitrogen $(\mathrm{N})$ content of the samples. Ether extract (EE) was determined with soxhlet (AOAC, 1995).

In the conventional rearing system, birds were placed in a naturally ventilated broiler house with adjustable windows. The birds were raised in pens with a concrete floor and litter material consisted of pine wood shavings. Four hundred one-day-old broilers were randomly allocated by body weight to two groups, which were then sub-divided into four replicates of 50 birds each and kept in four pens $(1.40 \times 3.00 \mathrm{~m})$. The birds were housed at a density of 12 chicks per square metre. Birds in four of the eight replicate pens were fed a basal diet, while the remaining animals were fed a diet with EOM. Each pen was equipped with two hanging feeders ( $5 \mathrm{~cm}$ feeder space per bird) and one bell drinker. Each pen contained a thermostatically controlled electric brooder, which was used to provide additional heat during brooding. The ambient temperature was maintained initially at $33 \pm 1{ }^{\circ} \mathrm{C}$ for the first three days and was gradually decreased over three weeks to acclimatize chicks to natural environmental conditions.

All of the chicks were vaccinated against infectious bursal disease (D-78, Nobilis) and Newcastle disease (Hitchner B1, Intervet; LaSota, Intervet) on days 10, 16 and 28 via drinking water. Vaccination against coccidiosis was performed with one-day-old chicks via oral administration using a commercial vaccine (Livacox Q, Biopharm).

Mashed diets and water were provided ad libitum. Experimental feed mixtures in the organic and conventional systems were prepared with maize, wheat, soybean meal and sunflower meal. Similar ingredients were used when formulating diets to avoid ingredient composition discrepancies. As established by EC Regulation 1804/99, at least $80 \%$ of the DM content of organic feed mixture was acquired from organically grown ingredients. Soybean meal (genetically modified organism (GMO)-free sources) was the only conventional feed ingredient included in the organic feed mixture at a level of $25 \%$. Lucerne meal, consisting of dried whole plants, which were grown organically, was added to the organic feed as a roughage source. The diets in mash form were prepared every two weeks and were stored in sacks in a cool place. The chemical composition of the ingredients and feed mixtures were analysed according to the AOAC (1995), and the metabolic energy was calculated according to Anonymous (1991).

The ingredients and nutritional composition of the starter and grower diets are presented in Tables 1 and 2, respectively. Isoenergetic and isonitrogenous diets were employed. Birds in the control group (CNT) were given untreated basal starter and grower diets from 0 to 28 days and 29 to 81 days, respectively. The remaining experimental diet was based on the basal diet and was supplemented with EOM. The diets did not contain an AGP, coccidiostats or other performance enhancer. The EOM was composed of six essential oils, viz. oregano oil (Origanum sp.), laurel leaf oil (Laurus nobilis), sage leaf oil (Salvia triloba), myrtle leaf oil (Myrtus communis), fennel oil (Foeniculum vulgare) and citrus peel oil (Citrus sp.), which were provided by Herba (Herba Co. Ltd., İmir, Turkey). The major EOM components were carvacrol, 1-8-cineole and thymol. They comprised $58.6 \%, 14.3 \%$ and $5.0 \%$ of the mixture, respectively. Thus, each $\mathrm{kg}$ feed supplemented with EOM provided $28.8 \mathrm{mg}$ carvacrol as the main plant bioactive. An essential oil premix used $952 \mathrm{~g}$ zeolite as a carrier for $48 \mathrm{~g}$ essential oil. This premix was added to the basal diet in $1000 \mathrm{~g} / \mathrm{ton}$ levels. Thus, $48 \mathrm{mg} \mathrm{EOM}$ were added to each $\mathrm{kg}$ of feed for the EOM treatment group. The EOM premix supplementation to diet was made at the expense of sawdust. The EOM preparation was added to an equal amount of sawdust, homogenized by mixer, and then the pre-mixture was added to the main mixture.

The EOM composition was analysed with the GC/MS system (HP 6890GC/5973 MSD, Agilent Technologies Canada Inc., Mississauga, ON, Canada). The EOM was distilled from the ground feed samples using the Clevenger distillation apparatus in accordance with United States Pharmacopeia (USP) methods and USP 23 NF18 (1995). First, the EOM was obtained by distilling $100 \mathrm{~g}$ ground feed samples in water for two hours using the Clevenger apparatus. The oil was then diluted with n-hexane (1:100) and injected into 
the GC/MS (HP 6890GC/5973 MSD) system with the following conditions: injection temperature: $250{ }^{\circ} \mathrm{C}$; injection split: 1/100; column: DB-17 $30 \mathrm{~m}, 0.25 \mu \mathrm{m}, 0.32 \mathrm{~mm}$ (Agilent); initial oven temperature: $70^{\circ} \mathrm{C}$, at a rate of $8^{\circ} \mathrm{C} / \mathrm{min}$; final oven temperature: $200^{\circ} \mathrm{C}$; injection vol.: $1 \mu \mathrm{L}$.

Table 1 Ingredient composition of experimental starter and grower diets

\begin{tabular}{|c|c|c|c|c|}
\hline \multirow{2}{*}{ Ingredients, g/kg } & \multicolumn{2}{|c|}{ Starter diets } & \multicolumn{2}{|c|}{ Grower diets } \\
\hline & Organic & Conventional & Organic & Conventional \\
\hline Maize & 396.5 & 414.0 & 389.0 & 398.0 \\
\hline Wheat & 198.6 & 190.0 & 200.0 & 200.0 \\
\hline Soybean meal (48\%) & 220.0 & 210.7 & 180.0 & 160.0 \\
\hline Lucerne meal (18\%) & 5.0 & 5.0 & 50.0 & 50.0 \\
\hline Sunflower meal (31\%) & 120.0 & 107.4 & 120.0 & 120.0 \\
\hline Sunflower oil & 22.2 & 35.9 & 27.0 & 38.0 \\
\hline Ground limestone & 15.6 & 14.6 & 14.0 & 14.0 \\
\hline Dicalcium phosphate (DCP) & 16.1 & 16.5 & 14.0 & 14.0 \\
\hline Sodium chloride & 2.5 & 2.5 & 2.5 & 2.5 \\
\hline Vitamin and mineral premix ${ }^{1}$ & 2.5 & 2.5 & 2.5 & 2.5 \\
\hline Sawdust ${ }^{2}$ & 1.0 & 1.0 & 1.0 & 1.0 \\
\hline
\end{tabular}

${ }^{1}$ Provided per kg of diet: $12000 \mathrm{IU}$ trans-retinol; $1500 \mathrm{IU}$ cholecalciferol; $30 \mathrm{mg}$ a-tocopherol acetate; 5 mg vitamin $\mathrm{K}_{3}$; $3 \mathrm{mg}$ vitamin $\mathrm{B}_{1} ; 6 \mathrm{mg}$ vitamin $\mathrm{B}_{2} ; 5 \mathrm{mg}$ vitamin $\mathrm{B}_{6} ; 0.03 \mathrm{mg}$ vitamin $\mathrm{B}_{12} ; 40 \mathrm{mg}$ nicotinamide; 10 mg pantothenic acid; $0.75 \mathrm{mg}$ folic acid; $0.075 \mathrm{mg} \mathrm{D}$-biotin; $375 \mathrm{mg}$ choline.

${ }^{2}$ Sawdust was replaced with the EOM premix when preparing diets supplemented with the EOM.

Table 2 Chemical composition of the starter grower diets fed in autumn and spring

\begin{tabular}{|c|c|c|c|c|c|c|c|c|}
\hline \multirow{3}{*}{ Analysed, \% } & \multicolumn{4}{|c|}{ Autumn } & \multicolumn{4}{|c|}{ Spring } \\
\hline & \multicolumn{2}{|c|}{ Starter diets } & \multicolumn{2}{|c|}{ Grower diets } & \multicolumn{2}{|c|}{ Starter diets } & \multicolumn{2}{|c|}{ Grower diets } \\
\hline & Organic & $\begin{array}{c}\text { Conven- } \\
\text { tional }\end{array}$ & Organic & $\begin{array}{c}\text { Conven- } \\
\text { tional }\end{array}$ & Organic & $\begin{array}{c}\text { Conven- } \\
\text { tional }\end{array}$ & Organic & $\begin{array}{c}\text { Conven } \\
\text { tional }\end{array}$ \\
\hline Dry matter & 90.0 & 90.1 & 90.3 & 90.2 & 92.1 & 92.0 & 92.0 & 92.1 \\
\hline Crude protein & 19.46 & 19.38 & 18.17 & 18.22 & 19.84 & 19.70 & 18.45 & 18.42 \\
\hline Ether extract & 6.92 & 6.78 & 7.10 & 7.04 & 7.01 & 6.85 & 7.15 & 7.12 \\
\hline Crude fibre & 5.81 & 5.74 & 7.21 & 7.12 & 5.92 & 5.87 & 7.28 & 7.23 \\
\hline Crude ash & 6.43 & 6.38 & 6.12 & 6.20 & 6.51 & 6.55 & 6.19 & 6.20 \\
\hline Calcium & 1.08 & 1.05 & 1.06 & 1.01 & 1.11 & 1.12 & 1.09 & 1.05 \\
\hline Total phosphorus & 0.65 & 0.68 & 0.62 & 0.63 & 0.67 & 0.70 & 0.63 & 0.62 \\
\hline \multicolumn{9}{|l|}{ Calculated, \% } \\
\hline $\mathrm{ME}(\mathrm{MJ} / \mathrm{kg})$ & 11.81 & 11.85 & 11.69 & 11.69 & 11.83 & 11.86 & 11.67 & 11.70 \\
\hline Lysine & 0.92 & 0.90 & 0.82 & 0.83 & 0.94 & 0.92 & 0.84 & 0.85 \\
\hline Methionine+cysteine & 0.66 & 0.63 & 0.62 & 0.63 & 0.67 & 0.64 & 0.63 & 0.64 \\
\hline Methionine & 0.33 & 0.33 & 0.31 & 0.32 & 0.34 & 0.33 & 0.32 & 0.32 \\
\hline
\end{tabular}

ME: metabolisable energy.

Broiler growth was evaluated by recording body weight, feed intake, feed conversion ratio (FCR) and mortality. The broiler body weights were measured individually on days 1, 42 and 81 . The mean initial chick 
weight was $43.9 \pm 0.4 \mathrm{~g}$ and $42.0 \pm 0.3 \mathrm{~g}$ in the autumn and spring trials, respectively. Feed intake per pen was recorded on days 42 and 81 . On the same days, the FCR was calculated as the amount of feed consumed per unit of body weight gain, adjusting for weight at hatch and bird mortality. Mortality was recorded daily as a percentage of mortal birds.

Broilers of both rearing systems were all slaughtered at 81 days of age. To determine the carcass yield and relative weight of the carcass cuts, six birds ( 3 male, 3 female) representing the average weight of the group $( \pm 4 \%$ ) were selected from each replicate pen (12 female and 12 male birds per each group). Then, 96 sampled birds were slaughtered by severing the jugular vein in the experimental processing unit of the institute eight hours after the feed withdrawal. The chicks were electrically stunned $(40 \mathrm{~V} ; 50 \mathrm{~Hz})$ before killing. Next, the carcasses were immersed into hot water $\left(60^{\circ} \mathrm{C}\right.$ for $\left.62 \mathrm{~s}\right)$, plucked and manually eviscerated. Then, the whole carcass was weighed and cut into parts. The breast (including pectoralis major and pectoralis minor), leg meat (including thigh and drumstick), wings and back were weighed. The percentage weight of the eviscerated carcasses was calculated as the ratio between the eviscerated carcass and live bodyweight. The percentages of breast, leg, wing and back were calculated in relation to the eviscerated carcass weight.

The numbers of birds observed outside were recorded three times (at 10:00, 13:00 and 16:00) during the day. At these times, the presence of the sun, in or out, was recorded. In addition, the presence or absence of rain was recorded. The daily mean temperature was obtained from the Meteorological Office in Aydın.

Two experiments were designed to determine the effect of the EOM and rearing system on performance and carcass characteristics of slow-growing broiler chicks under the seasonal conditions of autumn and spring. In each experiment, the data were analysed as a randomized complete block design with eight treatments arranged factorially, and the main effects (rearing system and EOM) and the interactions between these variables were tested by ANOVA using the GLM procedure of the SAS Institute (SAS, 2001). The dietary treatment means and their interactions with the rearing systems were compared using this form of analysis of variance. Data on feed intake, FCR and mortality were analysed per pen, whereas data on body weight and carcass characteristics were based on individual broilers. Additionally, a non-parametric test using the GLM procedure of the SAS Institute (SAS, 2001) was performed with the season and time of day as factors that affected the number of birds outside. An arc-sin transformation was applied before the percentage values were analysed. Duncan's multiple range test was performed to detect differences among treatments. All differences were considered significant at $P<0.05$.

\section{Results}

The broiler chicken performance parameters, including body weight, feed intake, FCR and mortality, are presented in Table 3, which shows the results obtained from the autumn and spring trials. In the autumn trial, the rearing system affected all of the performance indices within a high statistical significance $(P$ $<0.001$ ) at both 42 and 81 days of age. Organically reared birds gained less body weight with reduced feed intake, but exhibited a lower FCR compared with chicks grown conventionally. However, administering a diet with EOM worsened the FCR at $\mathrm{d} 42(P<0.01)$ and $\mathrm{d} 81(P<0.05)$, but did not influence the body weight and feed intake. A similar growth pattern was observed in the spring trial between days 1 to 42 , whereas the body weight, feed intake and FCR were not affected $(P>0.05)$ by rearing or EOM inclusion during the entire experimental period.

No health problems or predation losses were observed. The mortality rate was not influenced by any of the variables examined $(P>0.05)$. The mean overall flock mortality rate was less than $0.75 \%$ and $1.1 \%$ in the autumn and spring trials (Table 3$)$. No significant $(P>0.05)$ rearing system $\times$ EOM interaction was observed for any of the response criteria studied.

The meat cut carcass yield and percentage weight (i.e. breast, thigh, wing rearing system and back) were not affected by the rearing system or EOM inclusion $(P>0.05)$ (Table 4). However, the diet supplemented with the EOM increased breast yield in the spring trial $(P<0.05)$, but not in the autumn trial.

The herbage that was available at the end of the experiment was $1896 \mathrm{~g}$ and $1043 \mathrm{~g}$ in the autumn and spring trials, respectively. Less herbage was available in spring than in autumn (131 vs. $224 \mathrm{~g}$ DM per $\mathrm{m}^{2}$ paddock area) because of higher prevailing environmental temperatures. From these data, the available herbage DM per broiler per day was $14.9 \mathrm{~g}$ and $8.78 \mathrm{~g}$ in the autumn and spring trials, respectively. The $\mathrm{N}$ (\% $\mathrm{N}$ in the DM) and EE (\% EE in the DM) herbage content at the beginning of the experiment were $2.96 \%$ and $1.96 \%$ in autumn, respectively, and $2.72 \%$ and $1.69 \%$ in the spring, respectively. The average intake per bird per day over the eight replicates was $0.44 \mathrm{~g} \mathrm{~N}$ and $0.28 \mathrm{~g} \mathrm{EE}$ in autumn and $0.24 \mathrm{~g} \mathrm{~N}$ and $0.14 \mathrm{EE} \mathrm{g}$ in the spring. Herbage intake was not affected by dietary supplementation with EOM. 
Table 3 Performance of broilers reared organically or conventionally and fed a diet with or without essential oil mixture (EOM) in autumn and spring

\begin{tabular}{|c|c|c|c|c|c|c|c|c|c|c|c|c|c|c|c|c|c|}
\hline \multirow{3}{*}{$\begin{array}{l}\text { Rearing } \\
\text { system }\end{array}$} & \multirow{3}{*}{ EOM } & \multicolumn{8}{|c|}{ Autumn } & \multicolumn{8}{|c|}{ Spring } \\
\hline & & \multicolumn{4}{|c|}{0 - 42 day } & \multicolumn{4}{|c|}{0 - 81 day } & \multicolumn{4}{|c|}{0 - 42 day } & \multicolumn{4}{|c|}{0 - 81 day } \\
\hline & & $\begin{array}{c}\text { Body } \\
\text { weight } \\
\text { (g) }\end{array}$ & $\begin{array}{l}\text { Feed } \\
\text { intake } \\
(g) \\
\end{array}$ & FCR & $\begin{array}{c}\text { Mortality } \\
(\%)\end{array}$ & $\begin{array}{l}\text { Body } \\
\text { weight } \\
\text { (g) }\end{array}$ & $\begin{array}{c}\text { Feed } \\
\text { intake } \\
(\mathbf{g})\end{array}$ & FCR & $\begin{array}{c}\text { Mortality } \\
\text { (\%) }\end{array}$ & $\begin{array}{c}\text { Body } \\
\text { weight } \\
\text { (g) }\end{array}$ & $\begin{array}{c}\text { Feed } \\
\text { intake } \\
(g)\end{array}$ & FCR & $\begin{array}{c}\text { Mortality } \\
(\%)\end{array}$ & $\begin{array}{l}\text { Body } \\
\text { weight } \\
\text { (g) }\end{array}$ & $\begin{array}{c}\text { Feed } \\
\text { intake } \\
(\mathrm{g}) \\
\end{array}$ & FCR & $\begin{array}{c}\text { Mortality } \\
\text { (\%) }\end{array}$ \\
\hline \multirow{2}{*}{ Conventional } & Control & $1130^{\mathrm{a}}$ & $2412^{a}$ & $2.211^{\mathrm{b}}$ & 1.00 & $2930^{a}$ & $8760^{a}$ & $3.031^{b}$ & 1.00 & $1179^{a b}$ & $2762^{a}$ & $2.429^{a}$ & 1.00 & 2678 & 8162 & 3.095 & 0.50 \\
\hline & EOM & $1090^{b}$ & $2370^{a}$ & $2.253^{\mathrm{a}}$ & 0.50 & $2885^{a}$ & $8754^{\mathrm{a}}$ & $3.087^{\mathrm{a}}$ & 0.50 & $1203^{\mathrm{a}}$ & $2763^{a}$ & $2.379^{a}$ & 0.50 & 2722 & 8267 & 3.084 & 1.00 \\
\hline \multirow{2}{*}{ Organic } & Control & $1044^{\mathrm{C}}$ & $2079^{b}$ & $2.070^{d}$ & 0.0 & $2793^{b}$ & $8030^{b}$ & $2.925^{\mathrm{C}}$ & 0.0 & $1145^{\mathrm{b}}$ & $2533^{b}$ & $2.295^{\mathrm{b}}$ & 0.0 & 2683 & 8126 & 3.079 & 2.00 \\
\hline & EOM & $1038^{C}$ & $2112^{b}$ & $2.116^{\mathrm{C}}$ & 1.00 & $2774^{b}$ & $8052^{b}$ & $2.943^{\mathrm{C}}$ & 1.00 & $1171^{\mathrm{ab}}$ & $2566^{b}$ & $2.273^{b}$ & 1.00 & 2707 & 8117 & 3.043 & 1.00 \\
\hline Pooled SEM ${ }^{1}$ & & 12.61 & 24.18 & 0.013 & 0.47 & 29.01 & 62.00 & 0.016 & 0,47 & 14.70 & 15.89 & 0.024 & 0.47 & 27.72 & 70.62 & 0.021 & 0.85 \\
\hline \multicolumn{18}{|c|}{ Rearing system ${ }^{2}$} \\
\hline Conventior & nal & $1110^{\mathrm{a}}$ & $2391^{a}$ & $2.232^{\mathrm{a}}$ & 0.75 & $2907^{a}$ & $8757^{\mathrm{a}}$ & $3.059^{\mathrm{a}}$ & 0.75 & $1191^{a}$ & $2762^{a}$ & $2.404^{a}$ & 0.75 & 2700 & 8214 & 3.090 & 0.75 \\
\hline Organic & & $1041^{\mathrm{b}}$ & $2096^{b}$ & $2.093^{b}$ & 0.50 & $2784^{b}$ & $8041^{b}$ & $2.934^{b}$ & 0.50 & $1158^{b}$ & $2550^{b}$ & $2.284^{b}$ & 0.50 & 2695 & 8120 & 3.061 & 1.00 \\
\hline \multicolumn{18}{|l|}{$\mathrm{EOM}^{2}$} \\
\hline Control & & 1087 & 2245 & $2.141^{b}$ & 0.50 & 2861 & 8395 & $2.978^{b}$ & 0.50 & 1162 & 2647 & 2.362 & 0.50 & 2680 & 8144 & 3.087 & 1.25 \\
\hline EOM & & 1064 & 2241 & $2.184^{\mathrm{a}}$ & 0.75 & 2830 & 8403 & $3.015^{\mathrm{a}}$ & 0.75 & 1187 & 2665 & 2.326 & 0.75 & 2714 & 8190 & 3.064 & 1.00 \\
\hline \multicolumn{18}{|l|}{ Probability } \\
\hline Rearing sy & ystem & 0.0001 & 0.0001 & 0.0001 & 0.6110 & 0.0001 & 0.0001 & 0.0001 & 0.6110 & 0.0242 & 0.0001 & 0.0004 & 0.6110 & 0.8624 & 0.2048 & 0.1926 & 0.3970 \\
\hline EOM & & 0.0595 & 0.8635 & 0.0070 & 0.6110 & 0.2638 & 0.9044 & 0.0467 & 0.6110 & 0.0915 & 0.2991 & 0.1632 & 0.6110 & 0.2195 & 0.5208 & 0.2900 & 0.7747 \\
\hline $\begin{array}{l}\text { Rearing } \\
\text { systemEC }\end{array}$ & OM & 0.1616 & 0.1495 & 0.8849 & 0.1433 & 0.6570 & 0.8263 & 0.2820 & 0.1433 & 0.9667 & 0.3340 & 0.5767 & 0.1432 & 0.7340 & 0.4240 & 0.5705 & 0.3970 \\
\hline
\end{tabular}

a, b, c The means within a column, within main effects, and lacking a common superscript are significantly different $(P<0.05)$.

${ }_{2}^{1}$ Data are means of four replicate pens with SEM for each treatment.

2 Data were analysed as a $2 \times 2$ arrangement. 
Table 4 Carcass characteristics of broilers reared organically or conventionally and fed a diet with or without essential oil mixture (EOM) in two seasons

\begin{tabular}{|c|c|c|c|c|c|c|c|c|c|c|c|}
\hline \multirow{2}{*}{$\begin{array}{l}\text { Rearing } \\
\text { system }\end{array}$} & \multirow[b]{2}{*}{ EOM } & \multicolumn{5}{|c|}{ Autumn } & \multicolumn{5}{|c|}{ Spring } \\
\hline & & $\begin{array}{l}\text { Carcass } \\
\text { yield (\%) }\end{array}$ & $\begin{array}{c}\text { Thigh } \\
\text { yield (\%) }\end{array}$ & $\begin{array}{c}\text { Breast } \\
\text { yield (\%) }\end{array}$ & $\begin{array}{c}\text { Wing yield } \\
(\%)\end{array}$ & $\begin{array}{c}\text { Back yield } \\
(\%)\end{array}$ & $\begin{array}{l}\text { Carcass } \\
\text { yield (\%) }\end{array}$ & $\begin{array}{c}\text { Thigh } \\
\text { yield (\%) }\end{array}$ & $\begin{array}{c}\text { Breast } \\
\text { yield (\%) }\end{array}$ & $\begin{array}{c}\text { Wing yield } \\
(\%)\end{array}$ & $\begin{array}{c}\text { Back yield } \\
(\%)\end{array}$ \\
\hline \multirow[t]{2}{*}{ Conventional } & Control & 78.3 & 29.18 & 27.49 & 10.72 & 32.60 & 77.6 & 28.48 & 28.84 & 11.20 & 32.26 \\
\hline & EOM & 77.2 & 29.03 & 26.37 & 10.49 & 34.10 & 77.7 & 28.79 & 28.78 & 10.97 & 31.46 \\
\hline \multirow{2}{*}{ Organic } & Control & 77.5 & 28.56 & 27.08 & 10.38 & 33.96 & 77.7 & 28.61 & 29.05 & 11.00 & 31.33 \\
\hline & EOM & 76.9 & 29.08 & 27.04 & 10.75 & 33.11 & 77.4 & 29.97 & 28.22 & 10.98 & 30.82 \\
\hline \multicolumn{2}{|l|}{ Pooled SEM ${ }^{1}$} & 0.55 & 0.40 & 0.48 & 0.15 & 0.60 & 0.40 & 0.34 & 0.60 & 0.15 & 0.56 \\
\hline \multicolumn{12}{|c|}{ Rearing system ${ }^{2}$} \\
\hline \multicolumn{2}{|c|}{ Conventional } & 77.7 & 29.10 & 26.93 & 10.60 & 33.35 & 77.6 & 28.63 & 28.41 & 11.08 & 31.86 \\
\hline \multicolumn{2}{|c|}{ Organic } & 77.2 & 28.82 & 27.06 & 10.57 & 33.54 & 77.5 & 29.29 & 28.63 & 10.99 & 31.07 \\
\hline \multicolumn{12}{|l|}{$\mathrm{EOM}^{2}$} \\
\hline \multicolumn{2}{|l|}{ Control } & 77.9 & 28.87 & 27.28 & 10.55 & 33.28 & 77.7 & $28.54^{b}$ & 28.54 & 11.10 & 31.79 \\
\hline \multicolumn{2}{|l|}{ EOM } & 77.0 & 29.06 & 26.71 & 10.62 & 33.60 & 77.6 & $29.38^{\mathrm{a}}$ & 28.50 & 10.97 & 31.14 \\
\hline \multicolumn{12}{|l|}{ Probability } \\
\hline \multicolumn{2}{|c|}{ Rearing system } & 0.3740 & 0.4786 & 0.7886 & 0.8246 & 0.7541 & 0.7418 & 0.0654 & 0.7066 & 0.5376 & 0.1746 \\
\hline \multicolumn{2}{|l|}{ EOM } & 0.1218 & 0.6410 & 0.2412 & 0.6597 & 0.5972 & 0.7694 & 0.0202 & 0.9408 & 0.3977 & 0.2572 \\
\hline \multicolumn{2}{|c|}{ Rearing systemEOM } & 0.6558 & 0.4088 & 0.2756 & 0.0638 & 0.0568 & 0.5596 & 0.1331 & 0.1991 & 0.4971 & 0.7958 \\
\hline
\end{tabular}

${ }^{\mathrm{a}, \mathrm{b}}$ The means within a column, within main effects, and lacking a common superscript are significantly different $(P<0.05)$.

${ }^{1}$ Data are means of 24 chickens (six chickens per replicate pen) with SEM for each treatment.

2 Data were analysed as a $2 \times 2$ arrangement. 


\section{Discussion}

In autumn, organically grown broiler chicks gained relatively less bodyweight, with approximately $8 \%$ less feed intake, but yielded a lower FCR than their indoor counterparts. This may be because organically reared birds in the autumn trial spent more time outdoors (Figure 1). In autumn, birds went outside $30 \%$ more on average on both cloudy and sunny days than the birds in the spring. This may have promoted pasture intake and ultimately caused lower feed mixture consumption than in the spring. Another reasonable explanation for the reduction in feed intake observed in the organic system is that birds may have fulfilled their nutrient requirements with less feed mixture because of the additional nutrients derived from pasture intake.

Unlike the autumn conditions, chicks benefited less from the range area in the spring. Specifically, the number of birds outdoors decreased under bright sunlight at 1:00. In addition to this limited outdoor access, the short and sparse plant cover because of high temperatures towards the end of July may have caused the inefficiency of organically grown spring chicks.

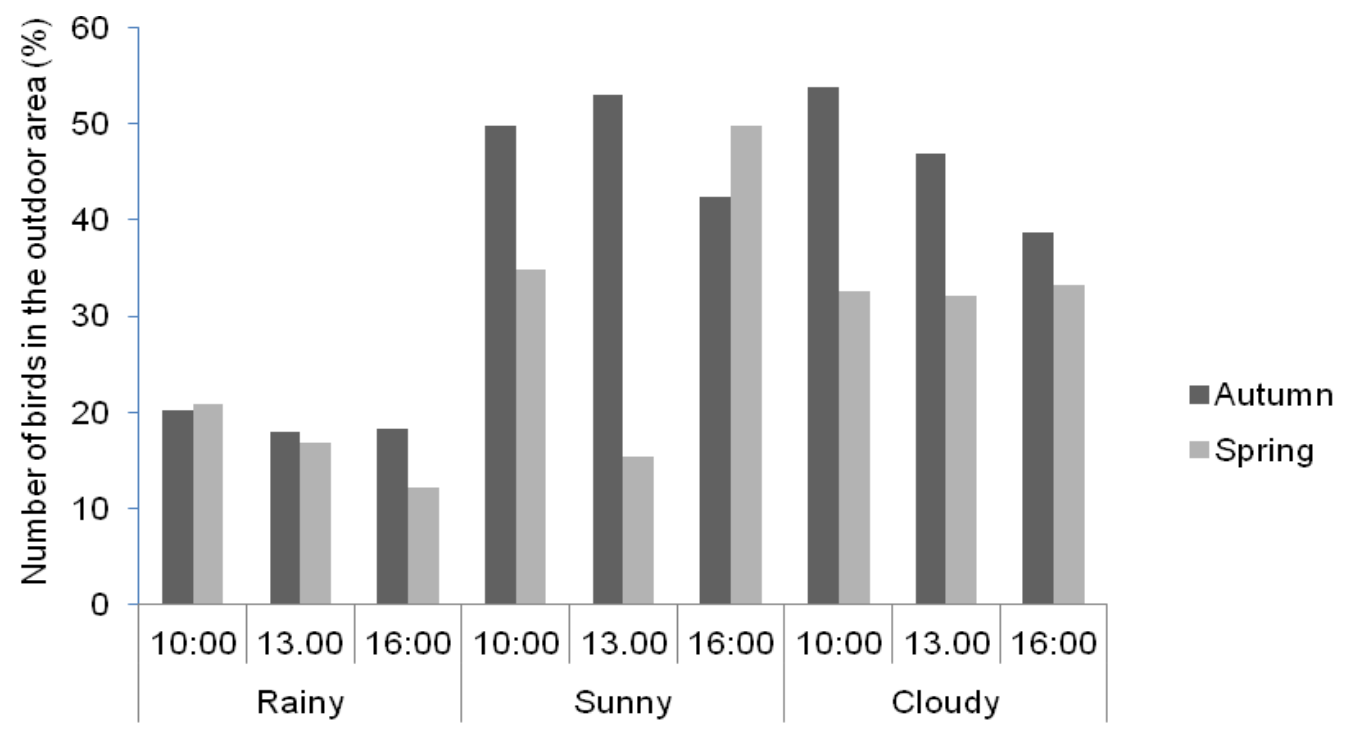

Weather condition and day time

$P$ Value for season, weather condition and day time: $P<0.0001$

Figure 1 Mean number of birds observed outside during different seasons, weather conditions and times of day.

In this study, the pasture, which consisted of a lucerne and trifolium mixture, was available for consumption outdoors throughout the autumn and spring trials. It was estimated that broilers grown in autumn could obtain up to $0.44 \mathrm{~g} \mathrm{~N}$ per day $(2.75 \mathrm{~g}$ of protein) and $0.28 \mathrm{~g} \mathrm{EE}$ per day from the herbage. An average daily intake per broiler of $25.6 \mathrm{~g}$ of crude protein and $9.53 \mathrm{~g}$ EE by feed mixtures were calculated for the entire experiment. The broilers received up to $10.7 \%$ and $2.9 \%$ of their daily protein and crude oil requirements, respectively, from the concentrates. Available pasture intake, in addition to basal feed mixture, may promote the improvement of the FCR, thereby supplying extra nutrient intake. In agreement with these findings, Rivera-Ferre et al. (2006) reported that broilers could obtain up to $2.41 \mathrm{~g}$ protein from $10.7 \mathrm{~g} \mathrm{DM}$ uptake per day from the herbage. Their study was the first attempt to estimate the amount of ingested herbage from free-ranging broilers in a lucerne-clover pasture. The results of several other related works agree with our findings. Fanatico et al. (2005) reported that pasture may contribute to nutrient intake, particularly if it is designed for poultry. Ponte et al. (2008) reported that differences in cereal-based feed consumption levels may be related to the composition or the levels of pasture intake, or both. Bassler et al. (2000) suggested that broilers' nutritional requirements that are supplied in an outdoor range differ widely and depend mainly on time of the year, quality and utilization of the range, which agrees with the present findings. However, in contrast with those research findings and assumptions, several researchers (Castellini et al., 2002b; Owens et al., 2006; Wang et al., 2009) have reported that the growth rate and feed efficiency of organic and free-range birds were poorer because of their increased mobility and less resting time, which 
increased the maintenance energy requirement. Extreme temperatures were also responsible for the deterioration in productive performance in birds with outdoor access. Other studies (Fanatico et al., 2005; Ponte et al., 2008; Mikulski et al., 2011) reported that outdoor access did not affect weight gain, feed intake or feed efficiency in slow-growing broilers with outdoor access. These discrepancies could be explained by the high general variation in an outdoor rearing system, such as herbage unavailability, bird density in the outdoor area, bird genotype and the season.

Few published studies have assessed the role of season, which could substantially affect growth, pasture quantity and quality, as well as the welfare of birds with outdoor access. Unfortunately, the design of our experiment was not able to test the significance of the difference between the two seasons because the work was not repeated in subsequent years. In one of the recent rare examples (Rack et al., 2009), performance variables of organically reared birds were significantly affected by season and feeding management (i.e. choice feeding and lack of a methionine supplement). In the present study, environmental conditions in the spring and autumn trial periods were rather different, especially in the mean and maximum temperatures. The spring study period (10 April to 3 July) harboured higher temperatures than late spring or early summer. As could be expected, birds reared in the spring exhibited inferior performances and a lower feed intake, bodyweight and FCR compared with those grown in autumn, probably because of the detrimental effect of heat stress on appetite.

In the present study, the effect of the rearing system on the meat cut carcass yield and the percentage weight (i.e. breast, thigh, wing and back ) was insignificant (Table 5), which agrees with the findings of other researchers (Fanatico et al., 2005; Wang et al., 2009; Mikulski et al., 2011). Additional nutrient intake in the organic system via pasture intake resulted in improved FCE, but not meat yield. Our findings support recent results (Mikulski et al., 2011) that indicated that measurements such as carcass yield and breast and thigh meat yield from the same breed (Hubbard Red JA) did not differ between birds reared in confinement and those grown with outdoor access. The assumption that the rearing system and pasture intake may affect overall carcass quality (Gordon \& Charles, 2002) was disproved in this and other related studies.

Essential oil mixture supplementation yielded conflicting responses, either detrimental or slightly improved, in chick performance indices in the autumn and spring trials. No clear reason could be deduced for this disparity. The effectiveness of dietary essential oil can be affected by numerous factors, including nutritional status, diet composition and exposure to environmental temperatures (Giannenas et al., 2003; Botsoglou et al., 2004; Lee et al., 2004). Broilers may not respond to the EOM when they are exposed to optimal environmental temperatures near the thermo-neutral zone for birds (20 to $24^{\circ} \mathrm{C}$ ) that prevailed in autumn in this study. However, in the spring, the heat stress conditions and plant bio-actives might facilitate the birds' ability to cope with depressive physiological changes caused by high environmental temperatures. Indeed, the interactions between the environmental challenges, phytogenic substances, diet composition and performance are complex, and despite excellent reviews on mode of action of essential oils (Brenes \& Roura, 2010; Wallace et al. 2010), there is still a dearth of experimental studies with extensive discussion of these aspects.

An impressive number of publications have described the promoter effect of EOs on growth and benefits on feed conversion efficiency in fast-growing, conventionally managed broiler chickens (Alçiçek et al., 2004; Windisch et al., 2008; Bozkurt et al., 2012a; Küçükyılmaz et al., 2012). The increased bodyweight and decreased FCR in response to dietary EOM observed in the spring trial are consistent with these research findings. However, they contradict a Waldenstedts (2003) report which observed that an oregano organic compound supplement did not influence the live weight, feed intake and FCR in organic broiler production using fast-growing broilers slaughtered at 55 days of age.

There were no meat yield benefits, except for thigh meat, in the spring season with a diet supplemented with an EOM. The overall findings demonstrated that feeding plant bio-actives to slow-growing broiler chickens does not display potential to increase meat yield, which remains true, regardless of the rearing system (organic vs. conventional). In accordance with our findings, some earlier studies reported no increases in carcass yield in broiler chickens fed diets with various essential oils (Basmacıoğlu et al., 2004; Jamroz et al., 2005; Çabuk et al., 2006).

\section{Conclusions}

Organically rearing slow-growing broiler chicks with pasture intake benefited profitable chicken meat production compared with their counterparts that were conventionally grown in confinement. However, such efficacy depends to a large extent on seasonal conditions at the sub-tropical zone, particularly at high environmental temperatures, and on the availability of adequate pasture intake. Our results suggest that seasonal autumn conditions, in which cooler temperatures prevailed and the herbage intake was at the upper limit, are favourable for efficient organic chicken production. Our experience with feeding plant 
essential oils to slow-growing chicks did not validate the assumption that phytogenic compounds may increase growth performance indices and carcass yield.

\section{Acknowledgement}

This project was supported by the Turkish Ministry of Agriculture and Rural Affairs, Project No: TAGEM/HAYSÜD/06/12/01/01.

\section{References}

Alçiçek, A., Bozkurt, M. \& Çabuk, M., 2004. The effect of a mixture of herbal essential oils, an organic acid or a probiotic on broiler performance. S. Afr. J. Anim. Sci. 34, 217-222.

Allen, P.C., Lydon, J. \& Danforth, H.D., 1997. Effects of components of Artemisia annua on coccidia infections in chickens. Poult. Sci. 76, 1156-1163.

Anonymous, 1991. Animal feeds determination of metabolisable energy (chemical method). Turkish Standards Institute (TSE), Publ. No. 9610. pp. 1-3.

AOAC, 1995. Official methods of analysis (16th ed.). Association of Official Analytical Chemists, Inc., Washington, DC, USA.

Basmacioğlu, H., Tokuşoğlu, Ö. \& Ergül, M., 2004. The effect of oregano and rosemary essential oils or alpha-tocopheryl acetate on performance and lipid oxidation of meat enriched with n-3 PUFA's in broilers. S. Afr. J. Anim. Sci. 34, 197-210.

Basmacioğlu, M.H., Baysal, Ş., Mısırlıoğlu, Z., Polat, M., Yılmaz, H. \& Turan, N., 2010. Effects of oregano essential oil with or without feed enzymes on growth performance, digestive enzyme, nutrient digestibility, lipid metabolism and immune response of broilers fed on a wheat-soybean meal diets. $\mathrm{Br}$. Poult. Sci. 51, 67-80.

Bassler, A., Ciszuk, P. \& Sjelin, K., 2000. Management of laying hens in mobile houses - A review of experiences. In: Ecological Animal Husbandries in the Nordic Countries. Eds: Hermansen, J.E., Lund, V. \& Thuen, E., Proceedings of Seminar No 303 of the Nordic Association of Agricultural Scientists. DARCOF Report No 2, Tjele, Denmark. pp. 45-50.

Botsoglou, N.A, Christaki, E., Florou-Paneri, P., Giannenas, I., Papageorgiou, G. \& Spais, A.B., 2004. The effect of a mixture of herbal essential oils or a-tocopheryl acetate on performance parameters and oxidation of body lipid in broilers. S. Afr. J. Anim. Sci. 34, 52-61.

Bozkurt, M., Küçükyılmaz, K., Çatlı, A.U. \& Çınar, M., 2009. Effect of dietary mannan oligosaccharide with or without oregano essential oil and hop extract supplementation on the performance and slaughter characteristics of male broilers. S. Afr. J. Anim. Sci. 39, 223-232.

Bozkurt, M., Küçükyılmaz, K., Çatlı, A.U., Çınar, M., Çabuk, M. \& Alçiçek, A., 2012a. Effects of administering an essential oil mixture and an organic acid blend separately and combined to diets on broiler performance. Arch. Geflugelkd 76, 81-87.

Bozkurt, M., Selek, N., Küçükyılmaz, K., Eren, H., Güven, E., Çatlı, A.U. \& Çınar, M., 2012b. Effects of dietary supplementation with a herbal extract on performance of broilers infected with a mixture of Eimeria species. Br. Poult. Sci. 53, 325-332.

Brenes, A. \& Roura, E., 2010. Essential oils in poultry nutrition: Main effects and modes of action. Anim. Feed Sci. Technol. 158, 1-14.

Çabuk, M., Bozkurt, M., Alçiçek, A., Akbaş, Y. \& Küçükyılmaz, K., 2006. Effect of herbal essential oil mixture on growth and internal organ weight of broilers from young and old breeder flocks. S. Afr. J. Anim. Sci. 36, 135-141.

Castellini, C., Dal Bosco, A., Mugnai, C. \& Bernardini, M., 2002a. Performance and behaviour of chickens with different growing rate reared according to the organic system. Ital. J. Anim. Sci. 1, 291-300.

Castellini, C., Mugnai, C. \& Dal Bosco, A., 2002b. Effect of organic production system on broiler carcass and meat quality. Meat Sci. 60, 219-225.

Cowan, M.M., 1999. Plant products as antimicrobial agents. Clin. Microbiol. Rev. 12, 564-582.

Dransfield, E. \& Sosnicki, A., 1999. Relationship between muscle growth and poultry meat quality. Poult. Sci. 78, 743-746.

Fanatico, A.C., Cavitt, L.C., Pillai, P.B., Emmert, J.L. \& Owens, C.M., 2005. Evaluatin of slow growing broiler genotypes grown with and without outdoor access: Meat quality. Poult. Sci. 84, 1785-1790.

Giannenas, I., Florou-Paneri, P., Papazahariadou, M., Christaki, E., Botsoglou, N.A. \& Spais, A.B., 2003. Effect of dietary supplementation with oregano essential oil on performance of broilers after experimental infection with Eimeria tenella. Arch. Anim. Nutr. 57, 99-106.

Gordon, S.H. \& Charles, D.R., 2002. Niche and Organic Chicken Products. Nottingham University Press, Nottingham, UK. 
Greathead, H., 2003. Plants and plant extracts for improving animal productivity. Proc. Nutr. Soc. 62, 279-290.

Husak, R., Sebranek, J.G. \& Bregendahl, K.A., 2008. A survey of commercially avaliable broilers marketed as organic, free range and conventional broilers for cooked meat yields, meat composition and relative value. Poult. Sci. 87, 2367-2376.

Jamroz, D., Wiliczkiewicz, A., Wertelecki, T., Orda, J. \& Sukorupinska, J., 2005. Use of active substances of plant origin in chicken diets based on maize and locally grown cereals. Br. Poult. Sci. 46, 485-493.

Küçükyılmaz, K., Çatı, A.U. \& Çınar, M., 2012. The effect of dietary essential oil mixture supplementation on the broiler performance, carcass yield and some internal organ weight. Kafkas Univ. Vet. Fak. 18, 291-296.

Lantinga, E.A., Neuteboom, J.H. \& Meijs, J.A.C., 2004. Sward methods. In: Herbage Intake Handbook (2nd edition). Ed: Penning, P.D., The British Grassland Society, Reading, pp. 23-52.

Lee, K.W., Everts, H. \& Beynen, A.C., 2004. Essential oils in broiler nutrition. Int. J. Poult. Sci. 3, $738-752$.

Mikulski, D., Celej, J., Jankowski, J., Majewska, T. \& Mikulska, M., 2011. Growth performance, carcass traits and meat quality of slower-growing and fast-growing chickens raised with and without outdoor access. Asian-Austral. J. Anim. Sci. 24, 1407-1416.

Owens, C., Fanatico, A., Pillai, P., Meullenet, J. \& Emmert, J., 2006. Evaluation of alternative genotypes and production systems for natural and organic poultry markets in the U.S. Proceedings of the XII. European Poultry Conference, 2006 September 10-14; Verona.

Ponte, P.I.P., Rosado, C.M.C., Crepso, J.P., Crepso, D.G., Mourao, J.L., Chaveırosoares, M.A., Bras, J.L.A., Mendes, I., Gama, L.T., Prates, J.A.M., Ferreira, L.M.A. \& Fontes, C.M.G.A., 2008. Pasture intake improves the performance and meat sensory attributes of free-range broilers. Poult. Sci. 87, 71-79.

Rack, A.L., Lilly, K.G.S., Beaman, K.R., Gehring, C.K. \& Moritz, J.S., 2009. The effect of genotype, choice feeding, and season on organically reared broilers fed diets devoid of synthetic methionine. J. Appl. Poult. Res. 18, 54-65.

Rivera-Ferre, M.G., Lantinga, E.A. \& Kwakkel, R.P., 2001. Herbage Intake and use of outdoor area by organic broilers: Effects of vegetation type and shelter addition. NJAS- Wagen. J. Life. Sc. 54, 279-291.

SAS, 2001. Statistical Analysis System user's guide: Statistics Edition, SAS Institute, Inc., Cary, NC, USA.

Shin, S. \& Lim, S., 2004. Antifungal effects of herbal essential oils alone and in combination with ketaconazole against Trichophyton spp. J. Appl. Microbiol. 6, 1289-1296.

United States Pharmacopeia, 1995. U.S. Pharmacopoeia \& the National Formulary: USP 23-NF18. United States Pharmacopeial Convention, Rockville.

Waldenstedt, L., 2003. Effect of vaccination against coccidiosis in combination with an antibacterial oregano (Origanum vulgare) compound in organic broiler production. Acta Agr. Scand. A-An. 53, 101-109.

Wallace, R.J., Oleszek, W., Franz, C., Hahn, I., Baser, K.H.C., Mathe, A. \& Teichmann, K., 2010. Dietary plant bioactives for poultry health and productivity. Br. Poult. Sci. 51, 461-487.

Wang, K.H., Shi, S.R., Dou, T.C. \& Sun, H.J., 2009. Effect of a free-range raising system on growth performance, carcass yield, and meat quality of slow-growing chicken. Poult. Sci. 88, 2219-2223.

Williams, P. \& Losa, R., 2001. The use of essential oils and their compounds in poultry nutrition. World Poult. 4, 14-15.

Windisch, W., Schedle, K., Plitzner, C. \& Kroismayr, A., 2008. Use of phytogenic products as feed additives for swine and poultry. J. Anim. Sci. 86, E140-E148. 